\title{
ANALISIS KINERJA MANAJERIAL BERDASARKAN PENERAPAN AKUNTANSI PERTANGGUNGJAWABAN, PARTISIPASI ANGGARAN DAN IMPLEMENTASI STRATEGI PADA PDAM TIRTA PAKUAN KOTA BOGOR
}

\section{THE MANAJERIAL PERFORMANCE ANALISYS PURSUANT TO APPLYING OF RESPONSIBILITY ACCOUNTING, BUDGET PARTICIPATION AND STRATEGY IMPLEMENTATION AT PDAM TIRTA PAKUAN BOGOR}

\author{
A. Lasmana, Nofiyati \\ Program Studi Akuntansi Fakultas Ekonomi Universitas Djuanda Bogor \\ Jl. Tol Ciawi No. 1, Kotak Pos 35, Kode Pos 16720, Telp/Fax : (0251) 8245155 \\ Email: andy.lasmana@unida.ac.id,nophinophnoph@yahoo.co.id
}

\begin{abstract}
This study aim is analyze influence of responsibility accounting, budgetary participation, and strategic implementation to manajerial performance at PDAM Tirta Pakuan Town of Bogor. Data in this study is a primer data that is questionair and interview with relevan parties. Sample in this study is 42 respondents are the lower managers until the middle managers. Instrument in this syudy are analized by validities, reliabilities, and classical assumption. The analyze techniquesed is multiple regression analyzed and hypothesis testing with $t$ test. The result is indicated that responsibility accounting, budgetary participation, strategic implementation have a positif significant impact to manajerial performance particially and simultan.
\end{abstract}

Key words: Responsibility accounting, budgetary participation, strategic implementation, manajerial performance.

\begin{abstract}
ABSTRAK
Penelitian ini untuk mengetahui pengaruh penerapan akuntansi pertanggungjawaban, partisipasi anggaran dan implementasi strategi terhadap kinerja manajerial pada PDAM Tirta Pakuan Kota Bogor. Data yang digunakan berupa data primer, kuesioner serta wawancara kepada pihak terkait. Sampel sebanyak 42 responden yaitu pimpinan tingkat bawah sampai pimpinan tingkat menengah. Instrumen penelitian melalui uji validitas, uji reliabilitas dan asumsi klasik . Analisis data regresi berganda dan uji hipotesis dengan uji t. Hasil penelitian bahwa ketiga variabel bebas berpengaruh positif dan signifikan terhadap variabel terikat secara parsial dan simultan.
\end{abstract}

Kata Kunci: Akuntansi pertanggungjawaban, partisipasi anggaran, implementasi strategi, kinerja manajerial. 


\section{PENDAHULUAN}

Kegiatan perusahaan yang semakin banyak menjadikan pemimpin perusahaan tidak mampu Setiap perusahaan didirikan dengan maksud untuk mencapai tujuan yang telah ditetapkan. Tujuan utama perusahaan adalah untuk memperoleh keuntungan yang maksimal dengan pertumbuhan perusahaan jangka panjang guna menjaga kelangsungan hidup perusahaan itu sendiri. Setiap perusahaan harus mempersiapkan secara matang serta meningkatkan etos kerja secara profesional untuk meningkatkan kinerja perusahaan agar dapat mencapai tujuan yang telah ditetapkan dan dapat bersaing dengan perusahaan lainnya.

Semakin kompleks kegiatan yang ada pada perusahaan, maka pemimpin perusahaan tidak hanya dapat mengandalkan kemampuan diri sendiri, tetapi memerlukan bantuan dan partisipasi dari pihak lain yang ada di dalam perusahaan. Pemimpin perusahaan memerlukan orang-orang yang dapat membantu dalam pelaksanan tugas-tugas yang ada, sehingga pemimpin dapat lebih fokus terhadap tujuan jangka panjang perusahaan. Seiring dengan berkembangnya skala usaha perusahaan dan semakin tajam persaingan dalam dunia usaha, maka semakin berkembang pula kebutuhan dan tuntutan atas informasi oleh pihak manajemen.

Pimpinan dapat mendelegasikan tugas kepada manajer melalui struktur organisasi yang ada. Para manajer bertugas merumuskan rencana perusahaan. Manajer lebih mengetahui pelaksanaan operasional perusahaan sehari-hari secara langsung. Manajer harus mengetahui dengan jelas wewenang yang didelegasikan kepadanya agar dapat diminta pertanggungjawaban. Manajemen membutuhkan informasi akuntansi untuk menilai pertanggungjawaban wewenang karena wewenang mengalir dari atasan ke bawahan, dan tanggung jawab mengalir dari bawahan ke atasan.

Salah satu alat untuk menilai kinerja manajer secara lebih baik adalah dengan adanya informasi akuntansi pertanggungjawaban. Informasi akuntansi pertanggungjawaban sangat dibutuhkan dalam pengendalian manajemen sebagai sarana untuk komunikasi, motivasi dan penilaian. Manajemen bertanggung jawab untuk memastikan bahwa pekerjaan itu telah dilaksanakan, maka informasi akuntansi membantu pembentukan orang-orang dalam organisasi dan memotivasi agar bersedia melaksanakan apa yang diinginkan manajer dan melakukan penilaian terhadap karyawan secara periodik untuk mengetahui sejauh mana pekerjaan telah dilaksanakan. Prestasi pusat pertanggungjawaban dapat ditentukan melalui pembentukan pusat-pusat pertanggungjawaban serta laporan anggaran dan realisasinya dari setiap pusat pertanggungjawaban sehingga harus disusun anggaran untuk setiap tingkatan manajemen.

Akuntansi pertanggungjawaban adalah sistem akuntansi yang mengakui adanya pusat-pusat pertanggungjawaban pada sebuah perusahaan. Pusat-pusat pertanggungjawaban mempunyai wewenang yang harus dipertanggungjawabkan dalam laporan tertulis. Laporan tersebut mencerminkan prestasi kerja manajer setiap pusat pertanggungjawaban dan pengendalian biaya (Iswahyudi, 2007). Penerapan akuntansi pertanggungjawaban yang baik harus menetapakan atau memberi wewenang secara tegas karena dari wewenang ini akan menimbulkan adanya tanggung jawab.

Pusat pertanggungjawaban mengartikan bahwa setiap unit kerja dalam organisasi dipimpin oleh seorang manajer yang bertanggung jawab. Suatu sistem untuk mengembangkan pengawasan akuntansi pertanggungjawaban harus dianggap sebagai tanggung jawab utama manajemen pelaksana dengan bantuan teknis dari departemen akuntansi. Para pemberi tugas harus menjelaskan dengan lengkap apa yang menjadi tujuan dan tanggung jawab yang harus dilaksanakan setiap tingkatan manajemen agar program yang direncanakan berhasil dicapai.

Penerapan sistem akuntansi pertangungjawaban yang baik akan menyebabkan terciptanya suatu pengendalian dan pengukuran prestasi kerja manajer. Akuntansi pertanggungjawaban juga sebagai sarana untuk mengevaluasi kemampuan setiap manajer, sehingga akan dibentuk landasan terciptanya suatu sistem pengukuran prestasi kerja manajer. Akuntansi pertanggungjawaban banyak dipakai oleh perusahaan-perusahaan dan badan usaha lainnya karena memungkinkan perusahaan untuk merekam seluruh aktivitas usahanya kemudian mengetahui unit yang bertanggung jawab atas aktivitas tersebut serta menentukan unit usaha yang tidak berjalan efisien. 
Anggaran adalah suatu rencana kuantitatif periodik yang disusun berdasarkan program yang telah disahkan sebagai alat manajemen dalam mencapai tujuan (Nafarin, 2008). Proses penyusunan anggaran pada dasarnya merupakan proses penetapan peran. Setiap manajer di dalam organisasi diberi peran untuk melaksanakan kegiatan pencapaian sasaran yang ditetapkan dalam anggaran. Manajer menengah dan bawah biasanya ikut berpartisipasi dalam proses penyusunan anggaran agar sasaran dapat tercapai. Partisipasi dalam penyusunan anggaran akan membuat manajer merasa dilibatkan egonya dan tidak sekedar terlibat dalam kerja sehingga diharapkan akan mendorong moral kerja dan inisiatif (Moheri, 2015).

Anthony dan Govindarajan (2005) terdapat tiga pendekatan yang digunakan dalam penyusunan anggaran yaitu top-down (pendekatan dari atas ke bawah), bottom-up (pendekatan dari bawah ke atas) dan pendekatan lain yang merupakan gabungan dari kedua pendekatan tersebut, yaitu pendekatan partisipasi. Inti dari partisipasi dalam penyusunan anggaran adalah diperlukan kerja sama antara seluruh tingkatan organisasi. Manajemen puncak biasanya kurang mengetahui bagian seharihari, sehingga harus mengandalkan informasi anggaran yang lebih rinci dari bawahannya. Manajer puncak mempunyai perspektif yang lebih luas atas perusahaan secara keseluruhan yang sangat vital dalam pembuatan anggaran secara umum. Menurut Garrison dan Noreen (2000), setiap tingkatan tanggung jawab dalam suatu organisasi harus memberikan masukan terbaik sesuai dengan bidangnya dalam suatu sistem kerjasama penyusunan anggaran.

Partisipasi bawahan dalam penyusunan anggaran kemungkinan juga dapat mempengaruhi kinerja manajerial karena dengan adanya partisipasi bawahan dalam menyusun anggaran maka bawahan merasa terlibat dan bertanggung jawab pada pelaksanaan anggaran. Bawahan diharapkan dapat melaksanakan anggaran dengan lebih baik dan pada akhirnya bisa meningkatkan kinerja manajerialnya.

Setiap lembaga atau institusi memiliki sejumlah tujuan atau harapan yang ingin dicapai. Tujuan dan harapan perusahaan dapat dicapai dengan sejumlah sumber daya yang memadai sehingga program atau rencana tindakan tersebut dapat dilaksanakan secara efektif demi terciptanya kinerja yang diharapkan (Jati, 2005).

Kinerja suatu perusahaan sangat dipengaruhi oleh kualitas dan bagaimana strategi dilaksanakan. Menurut Hunger dan Wheelen (2004), implementasi strategi adalah proses dimana manajemen mewujudkan strategi dan kebijakan dalam tindakan melalui pengembangan program, anggaran dan prosedur. Implementasi strategi merupakan alat untuk melakukan adaptasi dan merupakan penentu kinerja perusahaan. Manajemen perlu membangun pengendalian yang merupakan suatu proses dimana manajer mampu mempengaruhi anggota organisasi yang lain untuk mengimplementasikan strategi sehingga menjamin strategi sesuai dengan output (kinerja) yang diharapkan.

PDAM Tirta Pakuan Kota Bogor bergerak di bidang pengolahan air minum dan air kotor untuk meningkatkan kesejahteraan masyarakat yang mencakup aspek sosial, kesehatan dan pelayanan umum. Penerapan akuntansi pertanggungjawaban, partisipasi anggaran dan implementasi strategi menjadi penting pada perusahaan ini untuk mengetahui pelaksanaan tanggung jawab manajer pusat pertanggungjawaban dalam mencapai tujuan perusahaan yang telah ditetapkan. Perusahaan memerlukan suatu alat pengukuran kinerja untuk mengetahui seberapa baik manajer pusat pertanggungjawaban melaksanakan tanggung jawab tersebut.

PDAM Tirta Pakuan Kota Bogor menerapkan langkah-langkah penyusunan informasi akuntansi pertanggungjawaban, partisipasi anggaran dan implementasi strategi dalam operasionalnya. Hal ini ditandai dengan adanya struktur organisasi dan uraian tugas yang menerangkan secara jelas wewenang dan tanggung jawab tiap tingkatan manajemen serta adanya laporan kinerja yang merupakan hasil evaluasi kinerja/ tingkat kesehatan PDAM Tirta Pakuan Kota Bogor pada setiap tahunnya yang terdiri dari aspek keuangan, operasional dan administrasi.

Kinerja manajer PDAM Tirta Pakuan Kota Bogor dapat diukur dengan cara membandingkan anggaran dengan realisasinya. Selisih-selisih yang timbul dari analisis tersebut dapat menunjukkan prestasi dari manajer. Selisih-selisih tersebut dapat membantu manajer dalam mengidentifikasi 
persoalan-persoalan pokok dan kesempatan yang penting dalam hal pencapaian tujuan perusahaan. Berikut data anggaran pendapatan dan realisasi pendapatan PDAM Tirta Pakuan Kota Bogor Tahun 2010-2015 (dalam rupiah):

Tabel 1. Data Anggaran Pendapatan dan Realisasi Pendapatan Tahun 2010-2015

\begin{tabular}{cccc}
\hline Tahun & Anggaran Pendapatan & Realisasi Pendapatan & Persentase Realisasi \\
\hline 2010 & 117.488 .706 .000 & 119.308 .262 .039 & $102 \%$ \\
2011 & 141.821 .731 .000 & 135.085 .314 .723 & $95 \%$ \\
2012 & 154.119 .105 .000 & 160.503 .712 .054 & $104 \%$ \\
2013 & 182.856 .619 .000 & 181.654 .963 .170 & $99 \%$ \\
2014 & 196.975 .358 .000 & 193.213 .320 .702 & $98 \%$ \\
2015 & 209.680 .491 .000 & 209.652 .956 .794 & $99 \%$ \\
\hline
\end{tabular}

Sumber Data: www.pdamkotabogor.go.id, 2016

Tabel di atas menunjukkan bahwa pendapatan tahun 2010-2015 mengalami peningkatan setiap tahunnya, namum realisasi pendapatan mengalami fluktuasi yang tidak stabil. Tahun 2010 dan 2012 menunjukkan bahwa realisasi pendapatan lebih besar dari anggaran pendapatan yang dapat ditunjukkan pada presentase realisasi anggaran yaitu tahun 2010 sebesar 102\% dan tahun 2012 sebesar 104\%. Tahun 2011, 2013, 2014 dan 2015 menunjukkan bahwa realisasi pendapatan lebih kecil dari anggaran pendapatan yang dapat dillihat pada persentase realisasi pendapatan yaitu tahun 2011 sebesar 95\%, tahun 2013 sebesar $99 \%$, tahun 2014 sebesar 98\% dan tahun 2015 sebesar 99\%. Selisih antara anggaran pendapatan dan realisasi pendapatan pada tahun 2011, 2013, 2014 dan 2015 menunjukkan bahwa realisasi pendapatan masih kurang sesuai dengan target yang dianggarkan.

Selain selisih anggaran dan realisasi anggaran, kinerja manajerial juga dapat dilihat dari penyusunan anggaran biaya serta jumlah pelanggan. Bertambahanya jumlah pelanggan mencerminkan kinerja manajerial berupa implementasi strategi perusahaan yang telah diformulasikan serta efektifitas dan efisiensi biaya yang dianggarkan. Berikut data anggaran biaya serta pertambahan pelanggan pada PDAM Tirta Pakuan Kota Bogor tahun 20102015:

Tabel 1. Data Anggaran Biaya dan Jumlah Pelanggan Tahun 2010-2015

\begin{tabular}{llc}
\hline Tahun & Anggaran Biaya (dalam rupiah) & Jumlah Pelanggan \\
\hline 2010 & 92.416 .734 .000 & 94.995 \\
2011 & 114.396 .887 .000 & 103.841 \\
2012 & 123.860 .919 .000 & 112.111 \\
2013 & 151.883 .214 .000 & 118.424 \\
2014 & 181.365 .379 .000 & 129.312 \\
2015 & 185.906 .762 .000 & 138.000 \\
\hline
\end{tabular}

Sumber Data: www.pdamkotabogor.go.id, 2016

Berdasarkan tabel di atas dapat dilihat bahwa penyusunan anggaran biaya serta jumlah pelanggan pada tahun 2010-2015 mengalami peningkatan setiap tahunnya, namun dapat dilihat bahwa persentase kenaikan penyusunan anggaran biaya tidak sebanding dengan persentase kenaikan jumlah pelanggan yang ada. Berikut persentase kenaikan anggaran biaya dan pertambahan jumlah pelanggan berturut-turut. Pada tahun 2011 sebesar 23.8\% dan 9.3\%, tahun 2012 sebesar 8.3\% dan 8\%, tahun 2013 sebesar $22.6 \%$ dan 5,6\%, tahun 2014 sebesar 19.6\% dan $9.2 \%$ serta tahun 2015 sebesar 2,5\% dan $6,7 \%$. Data tersebut memperlihatkan bahwa pada tahun 2012 dan 2015 kenaikan penyusunan anggaran biaya sebanding dengan bertambahnya jumlah pelanggan, sedangkan pada tahun 2011, 2013 dan 2014 kenaikan penyusunan anggaran tidak sebanding dengan bertambahnya jumlah pelanggan. Hal ini kemungkinan disebabkan oleh faktor internal dan eksternal perusahaan.

\section{METODE PENELITIAN}

Penelitian dilakukan di PDAM Tirta Pakuan Kota Bogor yang berlokasi di Jalan Siliwangi Nomor 121 Bogor Jawa Barat dengan objeknya adalah akuntansi pertanggungjawaban, partisipasi anggaran, implementasi strategi terhadap kinerja manajerial. Populasi pada penelitian adalah pimpinan tingkat bawah sampai pimpinan tingkat menengah. Sampel berjumlah 42 
responden meliputi kepala bagian 10 orang dan subbagian 32 orang dengan teknik sampling jenuh. Desain penelitian merupakan penelitian kausalitas, yaitu untuk menganalisa pengaruh serta keterkaitan antarvariabel (Supomo dan Indriantoro, 2002). Data primer berupa jawaban kuesioner dari responden serta data sekunder profil perusahaan, struktur organisasi, anggaran perusahaan. Pengumpulan data kuesioner melalui personally administered questionnaires technique, yaitu penyampaian dan pengumpulan langsung kuesioner oleh peneliti (Indrianto dan Supomo, 2002). Variabel Independen (variabel bebas) terdiri dari :

1. Akuntansi pertanggung-jawaban

Hansen, Mowen (2009) menjelaskan tujuan akuntansi pertanggung-jawaban mengarahkan tindakan dan perilaku seseorang untuk mewujudkan tujuan perusahaan dan menyatakan manfaat diterapkannya akuntansi pertanggungjawaban dalam suatu perusahaan adalah pedoman menyusun anggaran, alat pengevaluasi kinerja, pemotivator manajer. Variabel diukur dengan menggunakan instrumen yang dikembangkan oleh Mulyadi (2001) dan digunakan oleh Prima (2014). Instrumen ini terdiri dari 24 poin pertanyaan yang diukur dengan menggunakan skala likert 5 poin berdasarkan penilaian dari sangat tidak setuju (1), tidak setuju (2), ragu (3), setuju (4), sampai sangat setuju (5).

2. Partisipasi anggaran

Setiap manajer berperan untuk melakukan kegiatan yang merupakan tujuan perusahaan berupa pencapaian anggaran yang telah ditetapkan. Manajer akan merasa terlibat egonya dalam partisipasi anggaran sehingga akan meningkatkan moral kerja dan inisiatifnya (Moheri, 2015). Variabel diukur dengan menggunakan instrumen yang dikembangkan oleh Kenis (1975) dan digunakan oleh Latuheru (2005) serta Mursyid (2011). Instrumen ini terdiri dari 8 poin pertanyaan yang diukur dengan menggunakan skala likert 5 poin.

3. Implementasi strategi

Menurut Hunger; Wheelen (2004), implementasi strategi yaitu kegiatan manajemen untuk mencapai kebijakan dan strategi sesuai anggaran, program, dan prosedur juga sarana penyesuaian dan merupakan penentu kinerja perusahaan. Variabel diukur dengan menggunakan instrumen yang digunakan oleh Faturrudin (2008). Instrumen ini terdiri dari 9 poin pertanyaan yang diukur dengan menggunakan skala likert 5 poin.

Variabel dependen $(\mathrm{Y})$ adalah kinerja manajerial. Mahoney et.al (1963) dalam Hafiz (2007) menyatakan bahwa kinerja manajerial mencakup fungsi-fungsi manajemen yaitu perencanaan, koordinasi, investigasi, supervisi, staffing, evaluasi, negosiasi, representasi. Konsep utama penilaian kinerja adalah kefektifan dan keefisiensian. Variabel diukur dengan menggunakan instrumen yang dikembangkan oleh Mahoney dan dikembangkan oleh Sumarno (2005) serta Mursyid (2011). Instrumen ini terdiri dari 9 pertanyaan yang diukur dengan menggunakan skala likert 5 poin.

\section{Pengujian Instrumen}

\section{Uji validitas}

Pengujian ini dilakukan dalam menilai sah atau tidaknya kuesioner menggunakan bivariate pearson correlation. Instrumen valid jika bisa mengungkap dan mengukur data secara tepat dengan syarat $r_{\text {hitung }}>$ $r_{\text {tabel. }}$

Tabel 3. Hasil uji validitas

\begin{tabular}{|c|c|c|c|c|}
\hline \multirow[t]{2}{*}{ Variable } & \multicolumn{2}{|c|}{ Nilai Koefisien } & \multirow[t]{2}{*}{ Rtabel } & \multirow[t]{2}{*}{ Ket. } \\
\hline & Terbesar & Terkecil & & \\
\hline Akuntansi Pertanggung-jawaban & 0,809 & 0,376 & 0,257 & Valid \\
\hline Partisipasi Anggaran & 0,898 & 0,508 & 0,257 & Valid \\
\hline Implementasi Strategi & 0,915 & 0,578 & 0,257 & Valid \\
\hline Kinerja Manajerial & 0,903 & 0,383 & 0,257 & Valid \\
\hline
\end{tabular}

2. Pengujian reliabititas sebenarnya untuk pengukuran indikator kuesioner variabel. Kuesioner reiabel apabila tanggapan dalam keadaan konsisten terus menerus (Ghozali,
2005). Pengujian reliabilitas rumus pengujian adalah alpha cronbach yaitu apabila reliabilitas instrumen $r_{\text {hitung }} \geq 0,6$. 


\begin{tabular}{lccc}
\hline \multicolumn{1}{c}{ Variabel } & Nilai $(\propto)$ & $(\propto)$ Ketetapan & Ket. \\
\hline Akuntansi & 0,754 & 0,60 & Reliabel \\
Pertanggungjawaban & & & \\
Partisipasi Anggaran & 0,770 & 0,60 & Reliabel \\
Implementasi Strategi & 0,787 & 0,60 & Reliabel \\
Kinerja Manajerial & 0,760 & 0,60 & Reliabel \\
\hline
\end{tabular}

\section{Uji Asumsi Klasik}

\section{Uji Normalitas}

Ghozali (2005), untuk pengujian rumus (model regresi variabel) berdistribusi normal/mendekati normal.

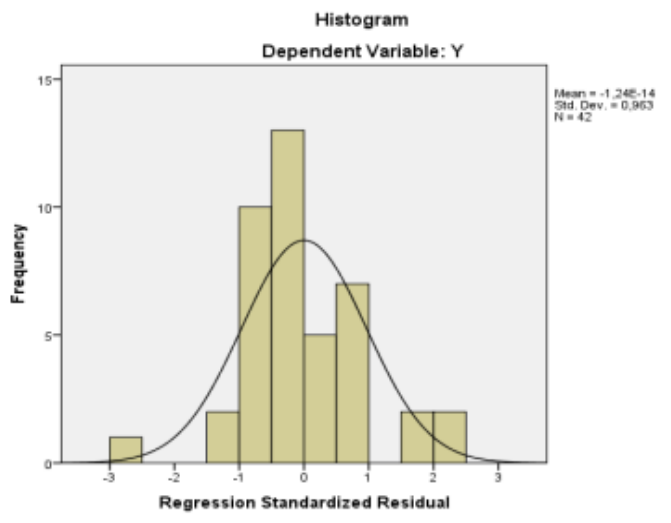

Gambar 1. Hasil uji normalitas data menggunakan histogram

menunjukkan data pada grafik histogram berdistribusi normal karena didapatkan kurva membentuk garis simetris terhadap mean (U).

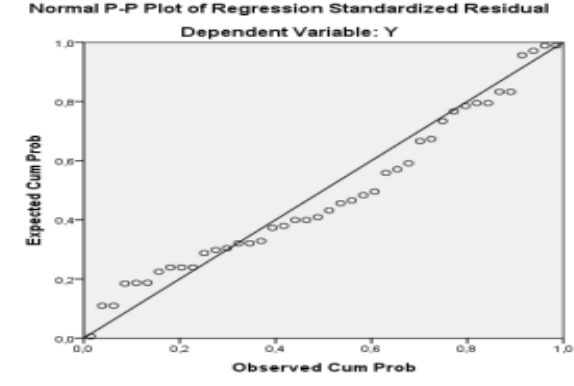

Gambar 2. Hasil uji normalitas data menggunakan normal probability plot menunjukkan bahwa uji normalitas tepenuhi karena data (titik) mengikuti arah diagonal dan terletak menyebar diarea garis diagonal, menunjukkan asumsi normalitas terpenuhi.

2. Uji Multikolonieritas

Menguji hubungan antar variabel bebas (independen). Model sebaiknya tidak terdapat korelasi antar variabel ditunjukkan pada nilai VIF (variance inflation factor) \& tolerance (jika besar VIF < 10 dan tolerance $>0,10$ )

Tabel 5. Hasil uji multikolonieritas

\begin{tabular}{lcc}
\hline \multicolumn{1}{c}{ Model } & \multicolumn{2}{c}{ Collinearity Statistics } \\
\cline { 2 - 3 } & Tolerance & VIF \\
\hline Akuntansi Pertanggungjawaban & 0,238 & 4,203 \\
Partisipasi Anggaran & 0,157 & 6,359 \\
Implementasi Strategi & 0,209 & 4,785 \\
\hline
\end{tabular}

Berdasarkan tabel 3.3. data telah memenuhi uji multikolonieritas berarti antar variabel tidak terjadi multikolonieritas.

3. Uji Heteroskedastisitas

Ghozali (2005), pengujian model regresi guna mencari perbedaan atau persamaan varians melalui pola gambar scatterplot.

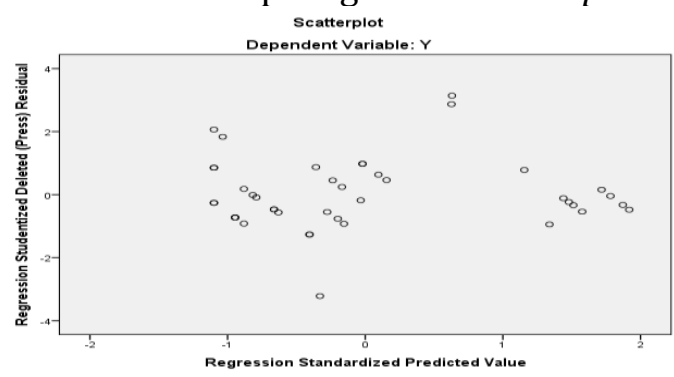

Gambar 3. Hasil uji heterokedastisitas
Menunjukkan data (titik-titik) menyebar dengan suatu pola yang jelas di atas dan di bawah angka 0 pada sumbu $Y$, dapat disimpulkan model regresi tidak terjadi heterokedastisitas.

\section{Statistik Deskriptif}

Ghozali (2005), mengemukakan bahwa statistik deskriptif penggambaran atau pendeskripsian data melalui nilai rata-rata, maksimum, minimum, jumlah, range, varian, standar deviasi.

\section{Uji Hipotesis}

Model persamaan (regresi berganda):

$$
\mathbf{Y}=\mathbf{a}+\mathbf{b} 1 \mathbf{x} 1+\mathbf{b} 2 \mathbf{x} 2+\mathbf{b} 3 \mathbf{x} 3+\mathbf{e}
$$


Ghozali (2005), Analisis korelasi untuk menganalisa hubungan variabel serta. koefisien determinasi R2 mengukur kemampuan model menjelaskan variabel dependen.

\section{Uji F}

Menunjukkan apakah semua variabel bebas yang dimasukkan ke dalam model mempunyai pengaruh secara bersama-sama (simultan) terhadap variabel dependen (Ghozali,2005).

\section{Uji t}

Ghozali, (2005), bertujuan mencari pengaruh secara parsial variabel bebas tehadap variabel terikat yang pada model.

Tabel 6. Karakteristik Responden

\begin{tabular}{|c|c|c|c|}
\hline Karakteristik Responden & Keterangan & Jumlah & Persentase \\
\hline \multirow[t]{11}{*}{ Divisi/ bagian } & Penelitian dan Pengembangan & 3 & $7 \%$ \\
\hline & SPI & 5 & $12 \%$ \\
\hline & Keuangan & 4 & $10 \%$ \\
\hline & Sumber Daya Manusia & 3 & $7 \%$ \\
\hline & Perlengkapan dan Peralatan & 4 & $10 \%$ \\
\hline & Pelayanan Pelanggan & 5 & $12 \%$ \\
\hline & Transmisi dan Distribusi & 5 & $12 \%$ \\
\hline & Produksi & 4 & $10 \%$ \\
\hline & Perencanaan dan Pengawanan Teknik & 3 & $7 \%$ \\
\hline & Sekretariat & 6 & $14 \%$ \\
\hline & Total & 42 & $100 \%$ \\
\hline \multirow[t]{3}{*}{ Jenis Kelamin } & Laki-laki & 31 & $74 \%$ \\
\hline & Wanita & 11 & $26 \%$ \\
\hline & Total & 42 & $100 \%$ \\
\hline \multirow[t]{3}{*}{ Jabatan } & Kepala/ Kepala Bagian & 10 & $24 \%$ \\
\hline & Kepala Subbagian & 32 & $76 \%$ \\
\hline & Total & 42 & $100 \%$ \\
\hline \multirow{5}{*}{$\begin{array}{l}\text { Latar Belakang } \\
\text { Pendidikan }\end{array}$} & Ekonomi & 19 & $45 \%$ \\
\hline & Hukum & 4 & $10 \%$ \\
\hline & Teknik & 15 & $36 \%$ \\
\hline & Sosial & 4 & $10 \%$ \\
\hline & Total & 42 & $100 \%$ \\
\hline \multirow[t]{4}{*}{ Pendidikan Terakhir } & Strata 1 (Sarjana) & 37 & $88 \%$ \\
\hline & Strata 2 (Master) & 4 & $10 \%$ \\
\hline & Strata 3 (Doktor) & 1 & $2 \%$ \\
\hline & Total & 42 & $100 \%$ \\
\hline \multirow[t]{3}{*}{ Lama Bekerja } & 11-15 tahun & 8 & $19 \%$ \\
\hline & 16-20 tahun & 34 & $81 \%$ \\
\hline & Total & 42 & $100 \%$ \\
\hline
\end{tabular}

Tabel 7. Analisis Statistik Deskriptif Descriptive Statistics

\begin{tabular}{cccccc}
\hline & $\mathrm{N}$ & Min & Max & Mean & Std. Dev \\
\hline $\mathrm{Y}$ & 42 & 37 & 45 & 4,47 & 0,32 \\
$\mathrm{X} 1$ & 42 & 93 & 117 & 4,22 & 0,30 \\
\hline $\mathrm{X} 2$ & 42 & 39 & 50 & 4,32 & 0,35 \\
& & & & &
\end{tabular}




\begin{tabular}{llllll}
\hline $\mathrm{X} 3$ & 42 & 36 & 44 & 4,22 & 0,34 \\
\hline
\end{tabular}

Tabel 7. dilihat dari nilai minimum, maximun, mean dan standard deviasi menunjukkan bahwa responden memiliki kinerja yang baik, mempunyai akuntansi pertanggungjawaban yang baik dalam perusahaan, keterlibatan partisipasi penyusunan anggaran yang tinggi baik dalam mengusulkan maupun melaksanakan anggaran dan berperan aktif dalam implementasi strategi perusahaan.

Tabel 8. Rekapitulasi Tanggapan Responden

\begin{tabular}{clcc}
\hline No & \multicolumn{1}{c}{ Variabel } & $\begin{array}{c}\text { Nilai Rata-Rata } \\
\text { Skor Tanggapan }\end{array}$ & Ket \\
\hline 1 & Akuntansi Pertanggungjawaban (X1) & 4,21 & Setuju \\
2 & Partisipasi anggaan (X2) & 4,32 & Setuju \\
3 & Implementasi Stategi (X3) & 4,22 & Setuju \\
4 & Kinerja Manajerial (Y) & 4,71 & Setuju \\
\hline
\end{tabular}

Tabel 8. menunjukkan bahwa tanggapan responden atas kuesioner memiliki rata-rata setuju sehingga akuntansi petanggungjawaban, partisipasi anggaran, implementasi strategi mempengaruhi kinerja manajerial.

Tabel 9. Analisis Regresi Linier Berganda

\begin{tabular}{clrrr}
\hline & Model & \multicolumn{2}{c}{ Unstandardized Coefficients } & \multicolumn{2}{c}{ Standardized Coefficients } \\
\cline { 2 - 5 } & \multicolumn{2}{c}{ Std. Error } & Beta \\
\hline 1 & (Constant) &, 473 &, 224 & \\
& X1 &, 242 &, 107 &, 232 \\
& X2 &, 464 &, 115 &, 514 \\
X3 &, 229 &, 102 &, 247 \\
\hline
\end{tabular}

Berdasarkan tabel 8. diatas diketahui bahwa nilai dari persamaan regresi:

$$
\mathrm{Y}=0,473+0,242 X 1+0,464 X 2+
$$$$
0,229 \times 3+\text { e. }
$$

Persamaan regresi tersebut menunjukkan bahwa koefisien regresinya positif artinya terdapat pengaruh antara akuntansi pertanggungjawaban, partisipasi anggaran, dan implementasi strategi terhadap kinerja manajerial. Jika penerapan akuntansi petanggungjawaban baik, peran serta dalam partisipasi anggaran tinggi dan implementasi strategi baik maka akan meningkatkan kinerja manajerial, begitu pula sebaliknya. Sesuai dengan persamaan regresi yang diperoleh, maka model regresi tersebut dapat diintreprestasikan sebagai berikut:

1. Nilai konstanta $=0,473$. Hal ini bearti apabila nilai dari akuntansi pertanggungjawaban (X1), partisipasi anggaran (X2), dan implementasi strategi (X3) dianggap konstan, maka besarnya variabel dependen kinerja manajerial (Y) akan sebesar 0,473 satu satuan.

2. Nilai koefisien $b 1=0,242$. Hal ini berarti apabila nilai variabel akuntansi pertanggungjawaban (X1), mengalami kenaikan sebesar satu poin sementara variabel partisipasi anggaran (X2), dan implementasi strategi (X3) bersifat tetap maka besarnya variabel dependen kinerja manajerial (Y) mengalami peningkatan sebesar 0,242 satu satuan.

3. Nilai koefisien $b 2=0,464$. Hal ini berarti apabila nilai variabel partisipasi anggaran (X2) mengalami kenaikan sebesar satu poin sementara variabel akuntansi pertanggungjawaban (X1) dan implementasi strategi (X3) bersifat tetap maka besarnya variabel dependen kinerja manajerial $(\mathrm{Y})$ mengalami peningkatan sebesar 0,464 satu satuan.

Nilai koefisien $b 3=0,229$. Hal ini berarti apabila nilai variabel implementasi strategi (X3) mengalami kenaikan sebesar satu poin sementara variabel akuntansi pertanggungjawaban (X1) dan partisipasi anggaran (X2) bersifat tetap maka besarnya variabel dependen kinerja manajerial (Y) mengalami peningkatan sebesar 0,229 satu satuan. 
Correlations

\begin{tabular}{rlrrrr}
\hline & \multicolumn{2}{c}{ X1 } & X2 & X3 \\
\hline \multirow{3}{*}{ Y } & Pearson Correlation & 1 &, $768^{* *}$ &, $918^{* *}$ &, $818^{* *}$ \\
& Sig. (2-tailed) & &, 000 &, 000 &, 000 \\
& N & 42 & 42 & 42 & 42 \\
& Pearson Correlation &, $768^{* *}$ & 1 &, $788^{* *}$ &, $789^{* *}$ \\
X1 & Sig. (2-tailed) & 42 & 42 &, 000 &, 000 \\
\cline { 2 - 6 } & N &, $918^{* *}$ &, $788^{* *}$ & 12 & 42 \\
& Pearson Correlation &, 000 &, 000 & &, $044^{* *}$ \\
X2 & Sig. (2-tailed) & 42 & 42 & 42 & 42 \\
& N &, $818^{* *}$ &, $789^{* *}$ &, $844^{* *}$ & 1 \\
& Pearson Correlation &, 000 &, 000 &, 000 & 42 \\
X3 & Sig. (2-tailed) & 42 & 42 & 42 & 42 \\
& N & & &
\end{tabular}

Berdasarkan tabel 9. hasil pengolahan data dapat dilihat bahwa dengan melihat nilai Sig. (2-tailed) sebesar 0,000 dibandingkan dengan 0,10, maka dapat disimpulkan bahwa terdapat hubungan antara variabel akuntansi pertanggungjawaban, partisipasi anggaran dan implementasi strategi tehadap kinerja manajerial. Hubungan antara variabel masingmasing secara parsial adalah sebagai berikut:

1. Hubungan antara variabel akuntansi pertanggungjawaban dengan kinerja manajerial sebesar 0,768 yang artinya hubungannya kuat. Karena nilai koefisiennya bernilai positif maka hubungan akuntansi petanggungjawaban dengan kinerja manajerial yaitu apabila akuntansi pertanggungjawaban semakin baik (buruk) maka kinerja manajerial akan semakin meningkat (menurun).
2. Hubungan antara variabel partisipasi anggaran dengan kinerja manajerial sebesar 0,918 yang artinya hubungannya sangat kuat. Karena nilai koefisiennya bernilai positif maka hubungan partisipasi anggaran dengan kinerja manajerial yaitu apabila partisipasi anggaran semakin baik (buruk) maka kinerja manajerial akan semakin meningkat (menurun).

3. Hubungan antara variabel implementasi strategi dengan kinerja manajerial sebesar 0,818 yang artinya hubungannya sangat kuat. Karena nilai koefisiennya bernilai positif maka hubungan implementasi strategi dengan kinerja manajerial yaitu apabila implementasi strategi semakin baik (buruk) maka kinerja manajerial akan semakin meningkat (menurun).

Tabel 10. Hasil Pengujian Analisis Korelasi

\begin{tabular}{cclcc}
\hline Model & $\mathrm{R}$ & $R^{2}$ & Adjusted $R^{2}$ & Std. Error of the Estimate \\
\hline 1 &, $951^{\mathrm{a}}$ &, 904 &, 896 &, 10214 \\
\hline
\end{tabular}

Berdasarkan tabel 10. diperoleh nilai $\mathrm{R}=$ 0,951 adalah positif yang berarti hubungan kedua variabel bersifat searah serta Nilai R sebesar 0,951 yang menunjukkan hubungan sangat kuat pada kedua variabel. Analisis koefisien determinasi menunjukkan besarnya sumbangan presentasi Penerapan Akuntansi Pertanggungjawaban, Partisipasi Anggaran,
Implementasi Startegi. Berdasarkan hasil tabel 4.4. diperoleh nilai R2 sebesar 0,904 atau $90,40 \%$. Hal tersebut mengindikasikan bahwa variabel bebas dapat menjelaskan sebesar $90,40 \%$ pada variabel tidak bebas (terikat), sedangkan sisanya sebesar $9,60 \%$ pengaruh variabel diluar pengamatan seperti, komitmen organisasi, motivasi kerja, dan lainnya.

Tabel 11. Hasil Analisis Koefisien Determinasi Parsial

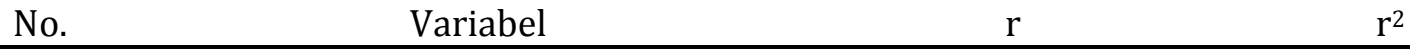




\begin{tabular}{llll}
\hline 1 & Akuntansi pertanggungjawaban & 0,768 & 0,590 \\
2 & Partisipasi anggaran & 0,918 & 0,843 \\
3 & Implementasi strategi & 0,818 & 0,669 \\
\hline
\end{tabular}

Berdasarkan tabel 11. tersebut dibandingkan dengan variabel lainnya menunjukan bahwa kontribusi variabel sedangkan variabel partisipasi anggaran penerapan akuntansi pertanggung-jawaban memiliki kontribusi paling tinggi dibandingkan $\left(\mathrm{X}_{1}\right)$ sebesar 0,590 (59\%) terhadap kinerja variabel lainnya. manajerial, kontribusi variabel partisipasi anggaran $\left(\mathrm{X}_{2}\right)$ sebesar $0,843(84,3 \%)$ terhadap variabel kinerja manajerial, sedangkan kontribusi variabel implementasi strategi $\left(\mathrm{X}_{3}\right)$ sebesar $0,669 \quad(66,9 \%)$ terhadap variabel kinerja manajerial. Jika dilakukan perbandingan, maka variabel penerapan akuntansi pertangungjawaban memiliki kontribusi pengaruh yang lebih rendah

\section{Uji F}

Pengujian hipotesis secara bersamasama (simultan) untuk menguji signifikasi pengaruh akuntansi pertanggungjawaban, partisispasi anggaran,implementasi strategi secara simultan berpengaruh terhadap kinerja manajerial dengan membandingkan $F_{\text {hitung }}$ dengan $\mathrm{F}_{\text {tabel }}$ pada tabel 4.8 berikut:

Tabel 12. Hasil Uji Terhadap Koefisien secara Simultan

\begin{tabular}{|c|c|c|c|c|c|c|}
\hline \multicolumn{7}{|c|}{$A_{N O V A^{a}}$} \\
\hline \multicolumn{2}{|c|}{ Model } & Sum of Squares & $d f$ & Mean Square & $F$ & Sig. \\
\hline 1 & Regression & 3,724 & 3 & 1,241 & 118,996 &, $000^{b}$ \\
\hline & Residual & ,396 & 38 & ,010 & & \\
\hline & Total & 4,120 & 41 & & & \\
\hline
\end{tabular}

a. Dependent Variabel: $Y$

b. Predictors Constant), $X 3, X 1, X 2$

Berdasarkan tabel 12. dapat dilihat bahwa nilai $F_{\text {hitung }}$ sebesar 118,996 dan nilai $\mathrm{F}_{\text {tabel }}$ untuk $\propto=10 \%$ dan $\mathrm{df}=42-2=40$ sebesar 2,84 dimana bisa dilihat bahwa $\mathrm{F}_{\text {hitung }}>$ dari $\mathrm{F}_{\text {tabel }}(118,996>2,84)$, maka $\mathrm{H}_{\mathrm{a}}$ diterima dan $\mathrm{H}_{0}$ ditolak, artinya penerapan akuntansi pertanggungjawaban (X1), partisipasi anggaran (X2) dan implementasi startegi
(X3) berpengaruh secara bersama-sama (simultan) terhadap kinerja manajerial (Y).

\section{Uji t}

Untuk mengetahui pengaruh variabel bebas menjelaskan variabel terikat. Kriteria yang ditentukan dalam uji t ini yaitu jika $t_{\text {hitung }}$ $>$ dari $t_{\text {tabel }}, \mathrm{H}_{\mathrm{o}}$ ditolak dan $\mathrm{H}_{\mathrm{a}}$ diterima, sedangkan jika $t_{\text {hitung }} \leq t_{\text {tabel }}, H_{o}$ diterima dan $\mathrm{H}_{\mathrm{a}}$ ditolak.

Tabel 13. Hasil Uji t

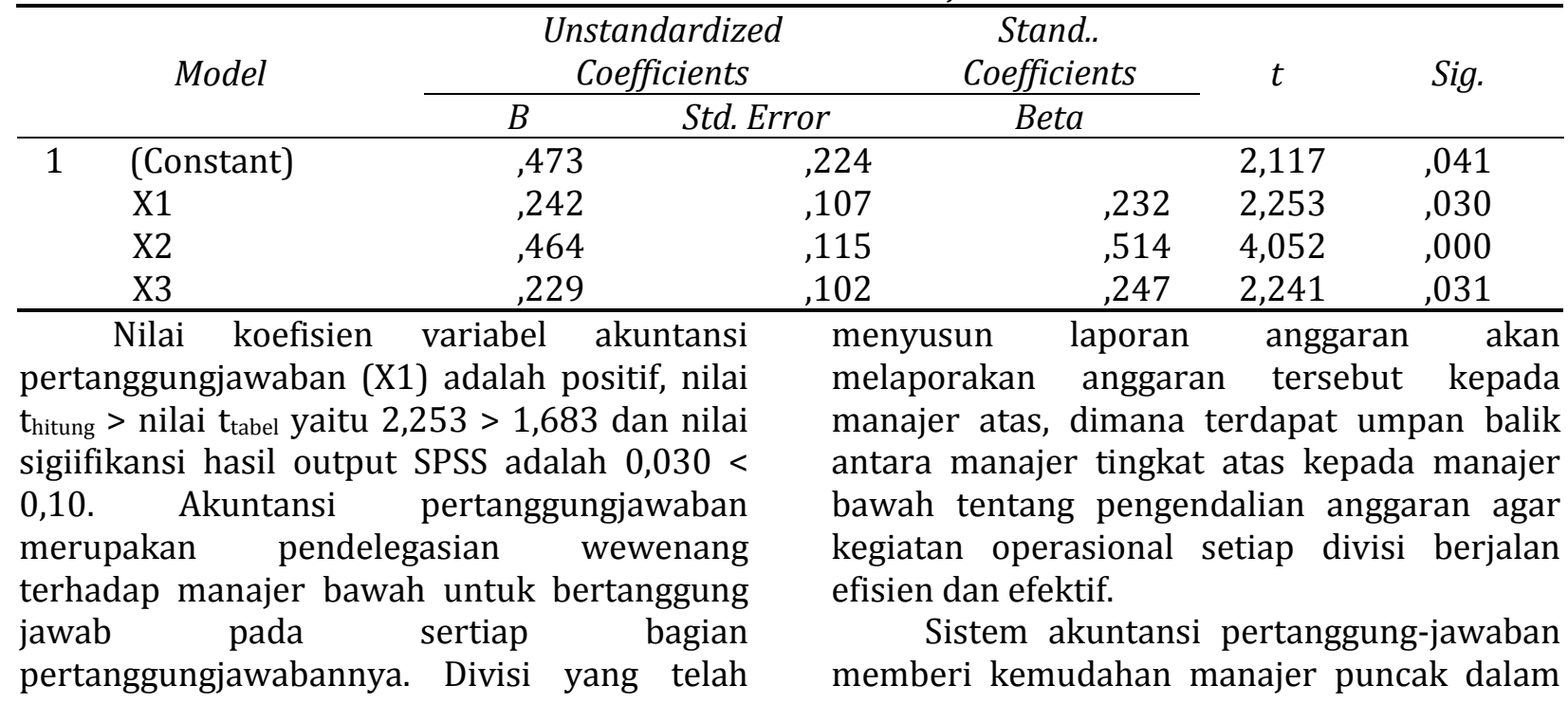


mengontrol pusat-pusat pertanggungjawaban. Pengendalian aktivitas melalui pemberian peran agar pimpinan merencanakan program kemudian membuat informasi hasil aktivitas pendapatan untuk menyusun anggaran. Peran seorang pimpinan akan semakin jelas meliputi proses penetapan orang dan alat sebagai pelaksana tugas. Akuntansi Pertanggungjawaban bermafaat untuk memotivasi pimpinan dengan sistem untuk memotivasi pimpinan yaitu penghargaan dan hukuman. Manajer yang diberi penghargaan akan termotivasi untuk meningkatkan kinerjanya. Penghargaan mendorong manajer secara sadar terdorong sehingga penghargaan berpengaruh pada manajer untuk termotivasi meningkatkan kinerjanya. Hasil penelitian ini mendukung penelitian yang dilakukan oleh Sari (2013) serta penelitian yang dilakukan oleh Prima (2014).

Nilai koefisien variabel partisipasi anggaran (X2) adalah positif, nilai $t_{\text {hitung }}>$ nilai $t_{\text {tabel }}$ yaitu 4,052 > 1,683 dan nilai sigiifikansi hasil output SPSS adalah 0,000 $<0,10$. Partisipasi anggaran bertujuan untuk menghindari perilaku negatif anggaran. Penyusunan anggaran pada setiap divisi atau unit kerja berdasarkan perencanaan dan aktivitas tahun lalu. Tiap-tiap bagian menerima formulir/ daftar isian dan menyusun konsep anggarannya masingmasing yang dimulai dengan membuat estimasi kegiatan semester II (JuliDesember) tahun berjalan. Estimasi terakhir adalah estimasi dijumlahkan dengan hasil kegiatan semester I sebagai acuan penyusunana anggaran tahun berikutnya.

Penyusunan estimasi terakhir dimaksud agar anggaran tahun mendatang menggambarkan hubungan dengan realisasi kegiatan yang diperkirakan dapat dicapai hingga akhir tahun berjalan. Anggaran tahunan dalam formulasi ditetapkan berdasarkan persetujuan data di dalam rapat koordinasi. Perbaikan yang diperlukan terhadap anggaran tahunan selesai tengah Desember dan selanjutnya direksi mengajukan anggaran tahunan definitif kepada badan pengawas agar disahkan. Jika partisipasi tidak dilakukan dengan benar maka akan mengurangi motivasi dan menurunan kemampuan dalam pencapaian sasaran anggaran. Hasil penelitian ini sesuai dengan hasil penelitian yang dilakukan oleh Hartini (2016) serta mendukung penelitian yang dilakukan oleh Moheri (2015).

Nilai koefisien variabel implementasi strategi adalah positif, nilai thitung > nilai ttabel yaitu 2,241 > 1,683 dan nilai sigiifikansi hasil output SPSS adalah 0,03 $<0,10$. Perusahaan menyusun rencana jangka panjang agar mempunyai rumusan dan tujuan perusahaan jangka lima tahun mendatang. Implementasi strategi yang baik mendorong pencapaian target tahunan anggaran berupa program-program tahunan seperti peningkatan laba bersih, penambahan jumlah pelanggan, pengaliran air bersih kepada pelanggan selama 24 jam, tercapainya rasio operasi hingga dibawah $100 \%$ dan peningkatan kesejahteraan dan tingkat keahlian pegawai secara berkesinambungan, jika program-program tahunan tercapai sesuai tujuan perusahaan. . Hasil penelitian ini sesuai dengan penelitian yang dilakukan oleh Sari (2013) serta mendukung penelitian lain yang dilakukan oleh Faturrudin (2008).

Berdasarkan tabel 4.8 bisa dilihat bahwa $\mathrm{F}_{\text {hitung }}$ lebihbesar dari $\mathrm{F}_{\text {tabel }} \quad(118,996>2,84)$, maka $\mathrm{H}_{a}$ diterima dan $\mathrm{H}_{0}$ ditolak, artinya penerapan akuntansi pertanggungjawaban (X1), partisipasi anggaran (X2) dan implementasi strategi (X3) berpengaruh secara bersama-sama (simultan) terhadap kinerja manajerial (Y). Penyusunan anggaran perusahaan ini mengalami peningkatan tiap tahun. Perusahaan berupaya untuk menaikkan pelayanan dan pendapatan sehingga dibutuhkan biaya-biaya. Penyimpangan anggaran masih dapat dikendaikan manajemen karena selisih tidak terlalu besar yaitu kurang dari 50\% - 100\% namun sebaiknya tetap meningkatkan kinerja manajerial anggaran dapat terealisasi ditahun berikutnya. Penetapan anggaran kurang sesuai dengan pertambahan jumlah pelanggan karena penetapan anggaran biaya meliputi biaya langsung usaha meliputi sumber air, biaya pengolahan air, transmisi dan distribusi, biaya perpompaan serta perencanaan teknik dan biaya tak langsung usaha meliputi umum dan keuangn,hubungan langganan dan lain-lain.

Pertambahan jumlah pelanggan adalah tugas bagian-bagian yang terkait di dalamnya seperti bagian pemasaran. Manajer bagian pemasaran semestinya berusaha agar jumlah sambungan langganan baru dan pemakaian air semakin meningkat. Hasil penelitian ini sesuai 
dengan penelitian yang dilakukan oleh Sari (2013) serta Hartini (2016).

\section{Kesimpulan}

1. Variabel penerapan akuntansi pertanggungjawaban, partisipasi anggaran, implementasi strategi berpengaruh positif dan signifikan terhadap kinerja manajerial secara parsial.

2. Variabel penerapan akuntansi pertanggungjawaban, partisipasi anggaran, implementasi strategi berpengaruh positif dan signifikan secara bersama-sama (simultan) terhadap kinerja manajerial.

\section{DAFTAR PUSTAKA}

Anthony dan Govindarajan. 2005. Management Control System. Jilid 1 dan 2. Terjemahan Kurniawan Tjakrawala dan Krista. Penerbit Salemba Empat. Jakarta.

Blocher, Edward J Chen, Kung H. Cokins, Gary dan Thomas W. Lin. 2007. Cost Management. Manajemen Biaya Penekanan Strategis. Terjemahan Susty Ambarriani. Penerbit Salemba Empat. Jakarta.

Cater, William. 2009. Cost Accounting. Dialihbahasakan oleh Krista. Akuntansi Biaya". Buku 2. Penerbit Salemba Empat. Jakarta.

Darlis, Edfan. 2002. Anaisis pengaruh Komitmen Organisasional dan Ketidakpastian Terhadap Hubungan Antara Patisipasi Anggaran dan Senjangan Anggaran. Jurnal Riset dan Akuntansi Indonesia. Vol. 5. No. 1.

Faturrudin. 2008. Pengaruh Penerapan Akuntansi Pertanggungjawaban dan Implementasi Manajemen Strategi Terhadap Kinerja Perusahaan (Perusahaan Manufaktur Go Public di Bursa Efek Indonesia). Fakultas Ekonomi Universitas Mercu Buana. Jakarta.

Garrison, Ray H. Noreen, Eric W, and Brewe, Peter C. 2000. Managerial
Accounting. Edisi 14. Dialihbahasakan oleh Kartika Dewi. Akuntansi Manajerial. Buku 1. Penerbit Salemba Empat. Jakarta.

Ghozali, Imam. 2005. Aplikasi Analisis Multivariate dengan Program SPSS. Edisi Pertama. Penerbit Universitas Diponegoro. Semarang.

Hafiz, Frisilia Wihasfina. 2007. Pengaruh Partisipasi Anggaran Terhadap Kinerja Manajerial Pada PT Cakra Compact Alumunium Industri. Fakultas Ekonomi. Universitas Sumatera Utara. Medan.

Hansen, Don R., And Maryanne M. Mowen. 2009. Management Accounting. $7^{\text {th }}$ Edition. South Western of Thomas Learning. Diterjemahkan oleh Dewi Fitrisari dan Deny Arnos Kwary. Akuntansi Manajemen. Buku ke 2. Edisi ke tujuh. Penerbit Salemba Empat. Jakarta.

Hartini, Diah Sri. 2016. "Pengaruh Partisipasi

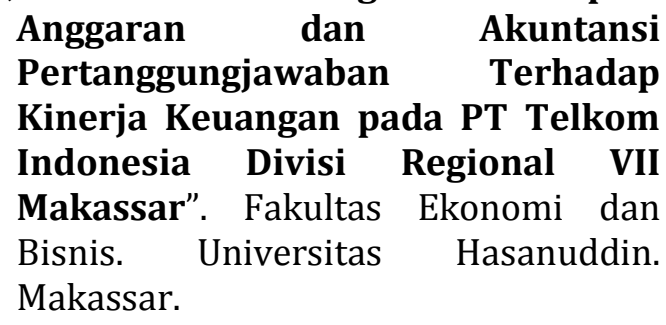

Hendikawati, Putriaji. 2015. Statistika Metode dan Aplikasinya dengan excel dan SPSS. DIKTI. Semarang.

Hidayat, Taufik. 2012. Analisis Pengaruh Penerapan Akuntansi Pertanggungjawaban Terhadap Kinerja Manajer Pusat Laba di Warung Paskal Bandung. Jurnal Akuntansi Vol. 4 No. 2. November 2012: 187.199.

Hunger dan Wheelen. 2004. Strategic Management Bussines Policy. Edisi 9. Tejemahan Julianto Agung $\mathrm{S}$. Yogyakarta. 
Ikhsan, Arfan. 2009. Akuntansi Manajemen Perusahaan Jasa. Penerbit Graha Ilmu. Yogyakarta.

Indrianto, Nur dan Bambang Supomo. 2002. Metode Penelitian Bisnis untuk Akuntansi dan Manajemen. Edisi Pertama. BPFE. Yogyakarta.

Iswahyudi, Dhian. 2007. Analisis Penerapan Akuntansi Pertanggungjawaban sebagai Alat Pengendalian Biaya Produksi dan Penilaian Kinerja Manajer Produksi pada PG. Meritjan Kediri. Jurnal Ekonomi Universitas Sumatera Utara.

Jati. 2005. Pengarahan dan Pengembangan Organisasi Motivasi, Artikel. 30 November 2005.

Jogiyanto, H.M. 2014. Metodologi Penelitian Bisnis: Salah Kaprah dan Pengalaman-pengalaman. Penerbit: BPFE-UG. Yogyakarta.

Kenis, I. 1975. Effect of Budgetary Goal Characteristics on Managerial Attitudes and Performance. Accounting Review. October 707-721.

Latuheru, Belianus Patria. 2005. Pengaruh Partisipasi Anggaran terhadap Senjangan Anggaran dengan Komitmen Organisasi sebagai Variabel Moderating (Studi Empiris pada Kawasan Industri Maluku). Universitas Kristen Petra Fakultas Ekonomi. Jurnal Akuntansi \& Keuangan. Vol 7, No. 2.

Marconi dan Siegel. 2003. Behavioral Accounting, South Western Publishing Company.

Matolla, Ridwan. 2011. Pengaruh Partisipasi Anggaran terhadap Kinerja dengan Locus of Control sebagai Variabel Moderating. Universitas Hasanuddin. Makassar.

Matz \& Ursy. 2001. Perencanaan dan Pengendalian. Jilid 1 . Terjemahan Herman Wibowo. Penerbit Erlangga. Jakarta.
Moheri, Yoyon. 2015. Pengaruh Partisipasi Anggaran Terhadap Kinerja Manajerial. Universitas Islam Sultan Agung. Semarang.

Mulyadi. 2001. Akuntansi Manajemen, Konsep, Manfat, Rekayasa. Edisi 3. YKPN. Yogyakarta.

Munandar. 2001. Budgeting: Perencanaan Kerja, Pengkoordinasian Kerja, Pengawasan Kerja. Edisi Ketiga belas. BPFE-UGM. Yogyakarta.

Mursyid, Raisyah. 2011. Pengaruh Partisipasi Anggaran, Komitmen Organisasi, Teknologi terhadap Kinerja Manajerial (Studi Empiris pada Perusahaan Manufaktur di Kabupaten Bogor). UIN Syarif Hidayatullah. Jakarta.

Nafarin. 2008. Penganggaran Perusahaan. Edisi 3. Salemba Empat. Jakarta.

Prima, Hilarius. 2014. Pengaruh Penerapan Akuntansi Pertanggjawaban Terhadap Kinerja Yogyakarta.Manajerial pada Hotel Berbintang di Daerah Istimewa Yogyakarta (Survei pada Hotel Berbintang 2-5 di Daerah Istimewa Yogyakarta). Universitas Atma Jaya Fakultas Ekonomi.

Robbins, Stephen P. 2003. Perilaku Organisasi. Terjemahan Diana Angelica. Penerbit Salemba Empat. Jakarta.

Rudianto. 2013. Akuntansi Manajemen: Informasi untuk Pengambilan Keputusan Manajemen. Grasindo. Jakarta.

Samryn, LM. 2001. Akuntansi Manajerial Suatu Pengantar. Edisi Pertama. Cetakan Kedua. PT. Raja Grafindo Persada. Jakarta.

Santoso, Singgih. 2002. Latihan SPSS Statistik Parametik. Penerbit PT. Elex Media Komputindo. Jakarta. 
Sari, Dian. 2013. Pengaruh Partisipasi Anggaran dan Akuntansi Pertanggungjawaban terhadap Kinerja Manajerial PT Pos Indonesia. E-Jurnal BINAR Akuntansi, 2 (1).

Sekaran. 2006. Research Methodes for Bussiness. Jilid 1 dan 2. Penerjemah Kwan Men You. Penertbit Salemba Empat. Jakarta.

Siagian, Sondang P. 2005. Manajemen Sumber Daya Manusia. Bumi Aksara. Jakarta.

Soekarno, E. 2002. Sistem Pengendalian Manajemen. Edisi Pertama. PT Gramedia Pustaka Utama. Jakarta.

Sugiyono. 2014. Metode Penelitian Kuantitatif, Kulalitatif, dan R \& D. Edisi Pertama. Cetakan Keenam. ALFABETA. Bandung.
Sumarno, J. 2005. Pengaruh Komitmen Organisasi dan Gaya Kepemimpinan Terhadap Hubungan antara Partisipasi Anggaran dan Kinerja Manajerial. Simposium Nasional Akuntansi Nasional Akuntansi VII. September. Solo.

Supriyono, R. A. 2000. Sistem Pengendalian Manajemen. Buku 1. Edisi Pertama. BPFE. Yogyakarta.

Umar, Husein. 2005. Metode Penelitian. Salemba Empat. Jakarta

Wahab, Abdul Solichin. 2008. Pengantar Analisis Kebijakan Publik. Universitas Muhammadiyah Malang Press. Malang

www.pdamkotabogor.go.id. Diakses pada tanggal 8 Oktober 2016. Pukul 8.00 WIB. 